\title{
Phytopathogenicity of fungi associated with crown rot of Guava (Psidium guajava)
}

\author{
Valentino $\mathrm{MJG}^{1^{*}}$, Pineda $\mathrm{FG}^{1}$, and Fandialan $\mathrm{MF}^{1}$ \\ ${ }^{\mathbf{1}}$ Department of Biological Sciences, College of Arts and Sciences, Central Luzon State University, Science City of Munoz, Nueva \\ Ecija, Philippines: email address- maryjhanevalentino@yahoo.com.ph
}

Valentino MJG, Pineda FG, Fandialan 2015 - Phytopathogenicity of fungi associated with crown rot of Guava (Psidium guajava). Plant Pathology \& Quarantine 5(1), 7-13, Doi 10.5943/ppq/5/1/2

\begin{abstract}
The present study determined the phytopathogenicity of eight species of fungi associated with the crown rot disease of guava fruits. These include Aspergillus flavus, A. fumigatus, A. japonicus var japonicus, A. niger, A. tamarii, Fusarium sambucinum, F. verticillioides and Lasiodiplodia theobromae. The study followed Koch's postulates for the in vivo infection of guava fruits and re-isolation of taxa for confirmation. Phytopathogenicity testing revealed that Aspergillus flavus, A. fumigatus, A. japonicus, A. niger and A. tamarii, were phytopathogenic causing crown rot of guava. Re-isolation of the phytopathogenic species on the infected plant tissue confirmed the identity of the fungal isolates.
\end{abstract}

Keywords - crown rot - fungi - guava - Koch's postulate - pathogen

\section{Introduction}

Guava (Psidium guajava) belonging to family Myrtaceae are well-known tropical fruits and are included among the "super fruits" due to its nutritive value. The medicinal properties of guava fruit, leaves, and other parts of the plant are also well-known in the traditional medicine (Joseph \& Mini 2014). Its fruit comprises high amounts of vitamins A, B1, B2, dietary minerals, lutein, zeaxanthine, lycopene, folic acid, potassium, copper, and manganese (Rahman et al. 2003). As cited by Hassimotto \& Genovese (2005), compared to other fruits, guava has a higher amount of minerals and pectin and about four times the amount of vitamin $\mathrm{C}$ as an orange. However, guava fruit ripens rapidly and are perishable due to their climacteric nature. Fruit ripening in guava is characterized by loss of green colour, softening, shrinkage, loss of brightness and rot development (Bassetto et al. 2005, Krishna \& Rao 2014).

Fungi and plants have a long history of opportunities for co-evolution and exert reciprocal evolutionary effects on one another. Fungal traits involved in pathogenesis have variance and respond to selection by plants, as is regularly demonstrated when pathogens overcome the disease resistance bred into crop plants. In addition, plant populations vary in their resistance to fungi (Berbee 2001, Geoffroy et al. 1999). As a group, fungi are the most important plant pathogens, both from the great financial losses and the number of different diseases they cause. They exist in a wide range of habitats as in living plants and are often present as symptomless endophytes, as biotrophic or necrotic parasites. Fungal distribution and structure of communities are greatly affected by the 
specific and non-specific biologically active substrates that have the potential to inhibit fungi, which are common constituents of plant tissues (Cooke \& Rayner 1984).

In guava fruits, fungi are the causal agents of anthracnose, light blight, stem rot, and crown rot. According to Misra (2006), guava is infected by around 177 pathogens and 167 of which infect various parts of the crop and about 17 are isolated with surface wash of fruits. Infection results in the appearance of discolored, malformed, or necrotic areas on the host plants. During infection, the pathogens grow, multiply, establish contact within the plant tissues, and procure nutrients from them (Streets 1969). As reported by Amusa et al. (2005), guava fruits infected with fungal disease had a significantly lower amount of carbohydrates, crude fibre, ash, fat, protein, calcium, iron, and phosphorus. More importantly, many fungal species produced mycotoxins which include deoxynivalenol, zearalenone, ochratoxin, aflatoxins, and fumonisins which can directly affect human health (Pittet 1998; Pitt 2000).

The present study was therefore initiated to determine which among the previously isolated molds are the primary post harvest phytopathogens causing crown rot in guava fruits. Results of the study would lead further to the utilization of the non-pathogenic fungi as biological control agents to numerous phytopathogens infecting various crops worldwide.

\section{Materials and Methods}

\section{Phytopathogenicity Test}

Phytopathogenicity test was guided by the Koch's postulates (Agrios 1997) which states that the pure culture of the organisms must produce the symptoms and signs of the disease when inoculated into the healthy plant and the suspected causal organisms must be re-isolated in pure culture from the inoculated plant and must be identical to the original organism.

\section{Preparation of Spore Suspension}

Spore suspensions of fungal isolates were prepared individually using a semi-solid Corn Meal Agar (0.2\%) and standardized to $5 \times 10^{7}$ spores $/ \mathrm{ml}$ using haemocytometer.

\section{Sterilization}

Guava fruits were subjected to surface disinfection prior to inoculation. Guava fruits were soaked in $10 \%$ sodium hypochlorite for 15 minutes and rinsed with sterilized distilled water. The fruits were soaked again in 10\% sodium hypochlorite for another 10 minutes and rinsed thrice with sterile distilled water. Finally, to remove excess water, the fruits were blot dried with sterilized tissue paper.

\section{Inoculation of Fungal Isolates}

Drop inoculation technique (Singh 2000) was used for infecting the guava fruit. Artificial wounds were made using sterile blood lancets. Each guava fruit was pricked 30 times near the crown and $1 \mathrm{ml}$ of fungal inoculum was inoculated on the artificial wounds. For the control, guava fruits were inoculated with sterile distilled water.

\section{Incubation}

Guava fruits were placed in clean culture bottles lined with moistened tissue paper to maintain the humidity inside the bottle. Then, culture bottles were covered with cheese cloth and were incubated at $28-30{ }^{\circ} \mathrm{C}$ for 7 days.

\section{Observation}

Close inspection on the fruits was made for the occurrence of crown rot infection. Symptoms diagnoses were based from Streets RT (1969), Agrios (1997), and Singh (2000). Symptoms are as follows: 1. The infection will occur through the cut ends and spreads into the crown of guava; 2 . At first, it will appear soft, slightly discolored spots of varying size; 3 . Molds 
will begin to grow at the center of the spots, mycelium of the fungus will be observed; 4 . The diseased portion will turn black and dries; 4. Black spots are seen near the crown portion.

\section{Re-isolation of the Fungi}

Fungi were re-isolated from the advancing margin of the infected tissue of the guava fruit and were inoculated in PDA plates. Cultures were incubated at $28-30^{\circ} \mathrm{C}$ for 5 to 7 days.

\section{Identification of the Isolated Fungi}

This was done to prove that the isolated organism is the same organism that has been inoculated causing the specific disease. Identification was based on cultural and morphological characteristics of the fungal isolates. For the cultural characterization, fungal isolates were grown in PDA plates using the triple point inoculation technique. Cultures were incubated at $28-30^{\circ} \mathrm{C}$ for 5 to 7 days. The number of days before growth, the rapidity and luxuriance of growth, and color of the colony were noted. While for the morphological characterization, agar block technique and direct microscopic observation were employed. Taxonomic criteria and key by Frazier \& Westhoff (1978) were used as basis for the confirmation of the identity of the fungal isolates.

\section{Results and Discussions}

There is a great diversity of fungal phytopathogens causing diseases to a wide range of agricultural crops which include species of genus Alternaria, Aspergillus, Botrytis, Fusarium, Lasiodiplodia, Monilinia, Penicillium, and Rhizopus (Ogawa et al. 1995). Li-Cohen \& Bruhn (2002) and Singh \& Sharma (2007) affirmed that the susceptibility of crops to fungal diseases is due to the high levels of sugars, carbohydrate, protein, fat and low $\mathrm{pH}$ values of fruits. Samson (1986) reported that the crude protein, carbohydrates, cruder fat content of the guava fruits were 7 , 11 , and $17.1 \%$, respectively. Strobel \& Mathre (1970) stated that fungal spores penetrate the surface of the fruits through artificial wounds; however, it does not always lead to infection and they cannot proceed beyond the stage of penetration and die without producing disease.

As presented in Table 1, among eight species of fungi associated with crown rot of guava, only five were found to be phytopathogenic causing crown rot on the wounded surface of guava fruits. These include all species Aspergillus fumigatus, A. niger, A. tamarii, A. japonicus, and A. flavus. The lesions caused by the phytopathogenic fungi consisted of dark brown to black discoloration on the infected area of the guava fruits after 7 days of incubation (Figs 1B-F).

Infections caused by the fungi vary in the appearance of symptoms and colonization of fungal mycelia. Crown rot disease in guava fruits was detected after 2 to 3 days of incubation. Brown discoloration on the crown of the fruits was observed on the second day of incubation, followed by the growth of mycelia on the $3^{\text {rd }}$ day. Brown discoloration turned black on the $4^{\text {th }}$ and $5^{\text {th }}$ day of incubation. Depression on the surface of fruits was also noticeable in fruits inoculated with Aspergillus niger and A. fumigatus on the $4^{\text {th }}$ to $5^{\text {th }}$ day of incubation (Figs $1 \mathrm{~B} \& \mathrm{~F}$ ). In addition, profuse sporulation of A. niger and A. japonicus on the surface of the infected guava fruits on the $5^{\text {th }}$ day of incubation were also observed (Figs $1 \mathrm{~B} \& \mathrm{C}$ ). While the lesions produced by $A$. flavus, A. fumigatus and A. tamarii mummified and blackened on the $7^{\text {th }}$ day of incubation (Figs 1D- F).

Accordingly, phytopathogenicity of genus Aspergillus in the recent study coincides with previous studies on Aspergilli as causal agents of fungal diseases. Kotan et al. (2009) characterized Aspergillus as wound-invading pathogen that causes decay on stored citrus fruits damaged by insects, animals, early splits, and mechanical harvesting. This also confirmed the reports of Chuku et al. (2008), Mathew et al. (2010), Akinmusire (2011) and Amadi et al. (2014), that A. flavus, A. flumigatus and A. niger are causal agents of postharvest spoilage in fruits including guava and tomatoes. Furthermore, members of genus Aspergillus are one of the major fungi species producing aflatoxin which were classified as toxin and carcinogenic compounds causing serious health implications, thus making fruits unfit for human and animal (Shenasi et al. 2002). 
No signs of crown rot in guava were observed in fruits treated with Fusarium sambucinum, $F$. verticilloides and Lasiodiplodia theobromae (Figs $1 \mathrm{G}$ - I) indicating their non- pathogenicity. These fungi produce the same results with the control group wherein slight change in colour was observed, which can be attributed to the ripening of the fruits (Fig 1A). Although mycelia of these fungi were also observed, no sign of crown rot disease was observed.

According to Pitt \& Hocking (1999), Fusarium verticillioides is an endophyte of maize. In addition, endophytic fungi are capable of living in host plants without causing any symptoms (Petrini et al. 1992). As stated by Munkvold \& Desjardins (1997), this symptomless infection can exist throughout the plant in leaves, stems, roots, grains, and the presence of the fungus is in many cases ignored because it does not cause visible damage to the plant. In a previous study by Rubini (2005), species of Fusarium and Lasiodiplodia along with other species of fungi were isolated as endophytes of cacao and were identified as potential antagonist of Crinipellis perniciosa, a causal agent of Witches' Broom Disease.

Contrary to present results of phytopathogenicity test, Cardoso (2002) and Punithalingam (1980) cited Lasiodiplodia as one of the causal agent of stem end rot, dieback, root rot, fruit rot, blights, gummosis, stem necrosis, leaf spot, and witches' broom disease of tropical crops. Misra \& Pandey (1999) also reported the phytopathogenicity of several Fusarium species causing wilt to guava plants. In addition, Fusarium are fumonisin producers, which are phytotoxic, damaging a wide variety of crops and have emerged as a highly visible animal and human health safety concern since they have been associated with many animal diseases such as leukoencephalomalacia and has been evaluated as possibly carcinogenic to humans (Fandohan et al. 2003). The results thus proved that the phytopathogenicity of fungi can be host and disease specific.

Table 1 Phytopathogenicity of fungal isolates

\begin{tabular}{lc}
\hline \hline \multicolumn{1}{c}{ Fungal isolates } & Phytopathogenicity \\
\hline \hline Aspergillus flavus Link & Phytopathogenic \\
Aspergillus fumigatus Fresenius & Phytopathogenic \\
Aspergillus niger van Tiegh & Phytopathogenic \\
Aspergillus tamarii Kita & Phytopathogenic \\
Aspergillus japonicus Saito var japonicas & Phytopathogenic \\
Fusarium sambucinum Fuckel & Non-phytopathogenic \\
Fusarium verticilloides (Saccardo) Niremberge & Non-phytopathogenic \\
Lasiodiplodia theobromae (Patouillard) Griffon and Maublanc & Non-phytopathogenic \\
\hline \hline
\end{tabular}

\section{Re-isolation of pathogenic fungi}

Five species of phytopathogenic fungi were re-isolated from the infected area and cultural and morphological characteristics were observed for further verification. Slight changes on the cultural characteristics of the isolated molds were observed which can be associated with the interaction of fungi with the chemical composition and availability of nutrients of the host plant. However, morphological and cultural characterization of the fungal isolates based on Frazier \& Westhoff (1978) proved the similarity of the initial inocula and the re-isolated pathogenic fungi. Thus, the confirmation of the fungal identity isolated from the infected fruits indicates that the five species of Aspergillus are the causal agents of crown rot of guava fruits.

In the study, the phytopathogenicity of the five species of Aspergillus in crown rot of guava fruits and the non-phytopathogenicity of Fusarium sambucinum, $F$. verticillioides and Lasiodiplodia theobromae were established. Thus, this would lead to the determination of the interaction and isolation of the bioactive compounds present in the pathogenic and the nonpathogenic species of fungi in search for biological control against fungal diseases in plants. 


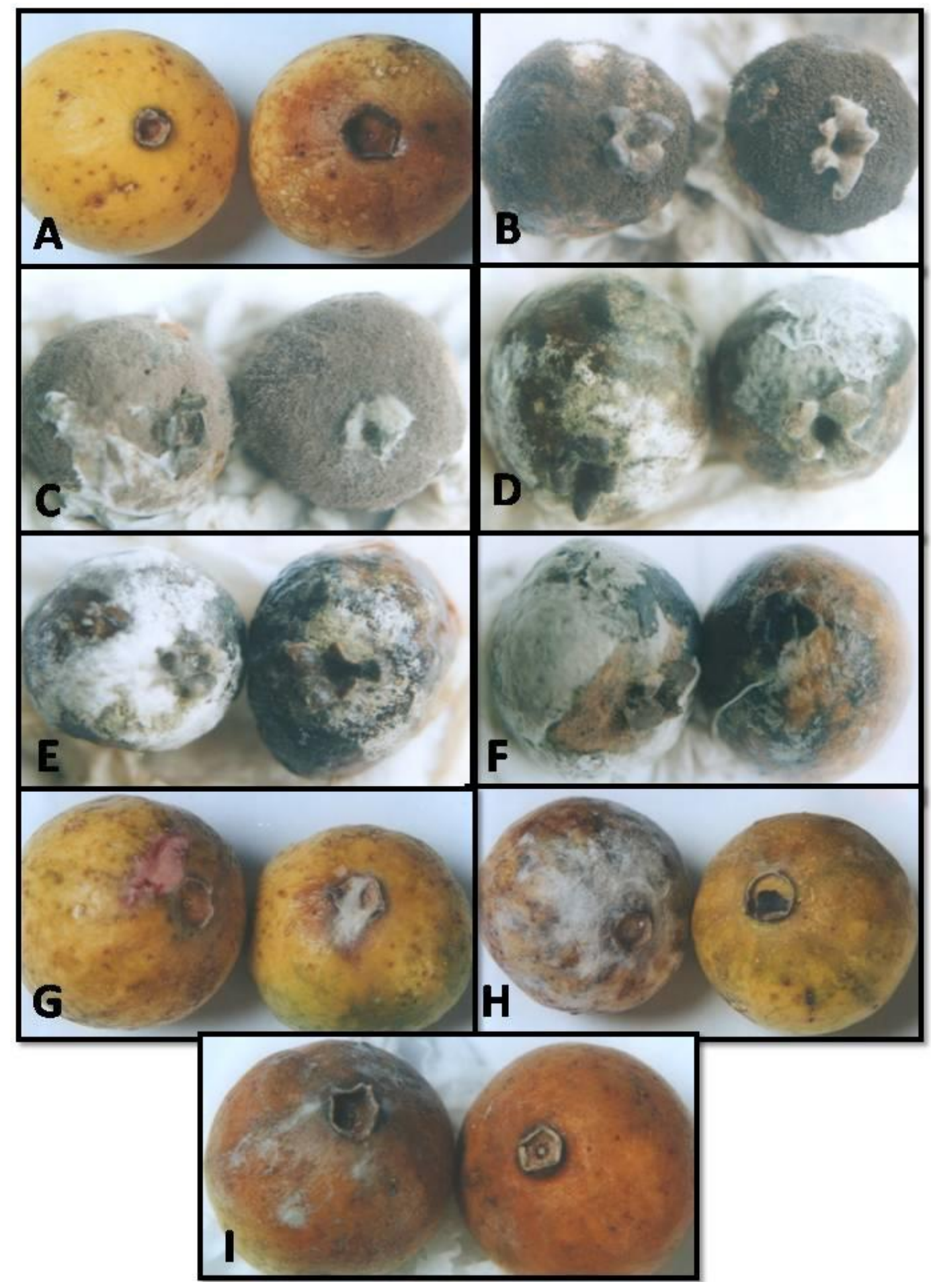

Figure 1 Guava fruits inoculated with (A) sterile distilled water, (B) A. niger (C) A. japonicus (D) A. flavus $(\mathrm{E})$ A. tamarii $(\mathrm{F})$ A. fumigatus $(\mathrm{G}) F$. verticilloides $(\mathrm{H}) F$. sambucinum (I) L. theobromae after 7 days of incubation

\section{Acknowledgement}

The authors would like to thank Farah Sebastian for providing the fungal isolates. We are also grateful for the support and assistance from the faculty and staff of the Department of Biological Sciences, Science city of Munoz, Nueva Ecija, Philippines.

\section{References}


Agrios, GN. 1997 - Plant pathology. 4th ed. Academic Press, London.

Akinmusire, OO. 2011 - Fungal species associated with the spoilage of some edible fruits in Maiduguri, Northern Eastern Nigeria. Advances in Environmental Biology. 5(1), 157-161.

Amadi JE, Nwaokike P, Olahan GS, Garuba T. 2014 - Isolation and identification of fungi involved in the post harvest spoilage of guava (Psidium guajava L.) in Awka Metropolis. International Journal of Engineering and Applied Sciences 4, 10.

Amusa NA, Ashaye OA, Oladapo MO, Oni MO. 2005 - Guava fruit anthracnose and the effects on its nutritional and market values in Ibadan, Nigeria. World Journal of Agricultural Sciences 1(2), 169-172.

Bassetto E, Jacomino AP, Pinheiro AL, Kluge RA. 2005 - Delay of ripening of 'Pedro Sato' guava with 1-methylcyclopropene. Postharvest Biology and Technology 35, 303-308.

Berbee ML. 2001- The phylogeny of plant and animal pathogens in the Ascomycota. Physiological \& Molecular Plant Pathology 59, 165- 187.

Cardoso JE, Maia CM, Pesso MNG. 2002 - Occurrence of Pestalotiopsis psidii and Lasiodiplodia theobromae causing stem rot of guava plants in the State of Ceara, Brazil. Fitopatologia Brasileira 27(3), 320.

Chuku EC, Ogbonna DN, Onuegbu BA, Adeleke MTV. 2008 - Comparative studies on the fungi and biochemical characteristics of snake guard (Trichosanthes Curcumerina linn) and tomato (Lycopersicon esculentum Mill) in Rivers State, Nigeria. Journal of Applied Sciences. 8(1), 168- 172.

Cooke RC, Rayner ADM. 1984 - Ecology of Saprothropic Fungi. London. Longman.

Fandohan P, Hell K, Marasas WFO, Wingfield MJ. 2003 - Infection of maize by Fusarium species and contamination with fumonisin in Africa. African Journal of Biotechnology 2 (12), 570- 579.

Frazier WC, Wesshoff DC. 1978 - Food Microbiology $3^{\text {rd }}$ ed. Tata Mc Graw Hill Publ. Co. Ltd. New Delhi

Geffroy V, Sicard D, De Oliveira JCF, Se Avignac M, Cohen S, Gepts P, Neema C, Langin T, Dron M. 1999 - Identification of an ancestral resistance gene cluster involved in the coevolution process between Phaseolus vulgaris and its fungal pathogen Colletotrichum lindemuthia-num. Molecular Plant and Microbe Interactions 12, 774- 784.

Hassimotto NM, Genovese MI. 2005 - Antioxidant activity of dietary fruits, vegetables, and commercial frozen fruit pulps. Journal of Agricultural \& Food Chemistry 53(8), 2928-2935.

Joseph B, Mini P. 2014 - Review on nutritional, medicinal and pharmacological properties of guava (Psidium guajava L.). Indian Journal of Science and Technology 7(5), 54-558.

Kotan R, Dikbas N, Bostan H. 2009 - Biological control of post harvest disease caused by Aspergillus flavus on stored lemon fruits. African Journal of Biotechnology 8(2), 209- 214.

Krishna KR, Rao DVS. 2014 - Effect of chitosan coating on the physiochemical characteristics of guava (Psidium guajava L.) fruits during storage at room temperature. Indian Journal of Science \&Technology 7(5), 554-558.

Li- Cohen E, Bruhn CM. 2002 - Safety of consumer handling of fresh produce. Journal of food production 65(8), 1287-1297.

Mathew S. 2010 - The prevalence of fungi on the post harvested guava (Psidium guajava L.) in Aksum. International Journal of Pharmaceutical Sciences and Research 1(10), 145-149.

Misra AK. 2006 - Wilt of guava - a disease of national importance. Indian Phytopathology 59(3), 269- 280.

Misra AK, Pandey BK. 1999 - Pathogenicity and evaluation of fungicides against guava wilt

pathogens. Journal of Mycology \& Plant Pathology. 29, 274-275.

Munkvold GP, Desjardins AE. 1997 - Fumonisins in maize. Can we reduce their occurrence? Plant Disease Journal 81, 556-564.

Ogawa JM, Dehr EI, Bird GW, Ritchie DF, Kiyoto V, Uyemoto JK. 1995 - Compendium of stonefruit diseases. APS Press, USA. 
Petrini O, Sieber TN, Toti L, Viret O. 1992 - Ecology, metabolite production, and substrate utilization in endophytic fungi. Natural Toxins 1, 185- 196.

Pitt JI . 2000 - Toxigenic fungi: which are important? Medical Mycology 38, 17- 22.

Pitt JI, Hocking AD. 1999 - Fungi and food spoilage. $2^{\text {nd }}$ ed. Aspen Publishers, Inc. Gaithersburg, Maryland.

Pittet A .1998 - Natural occurrence of mycotoxins in foods and feeds -an updated review. Revue de Medecine Veterinaire 149, 479-492.

Punithalingam E. 1980 - Plant diseases attributed to Botryodiplodia theobromae Pat. J. Cramer, Vaduz. Bibliography of Systematic Mycology 71, 1-123.

Rahman M, Begum K, Begum M, Faruque CAA. 2003-Correlationnand path analysis in guava. Bangladesh Journal of Agricultural Research 28, 93-98.

Rubini MR, Silva-Ribeiro RT, Pomella AWV, Maki CS, Araujo WL, Dos Santos DR, Azevedo JL. 2005 - Diversity of endophytic fungal community of cacao (Theobroma cacao L.) and biological control of Crinipellis perniciosa, causal agent of witches' broom disease. International Journal of Biological Sciences 1, 24-33.

Samson JA. 1986 - Tropical Fruit. Longman group, potentials of the star apple in Nigeria. Denton, O.A, UK.

Shenasi M, Aidoo KE, Candlish AAG. 2002 - Microflora of date fruits and production of aflatoxin at various stages of maturation. International Journal of Food Microbiology, 79: $113-119$.

Singh RS. 2000 - Diseases of Fruit Crops. Science Publishers, Inc., Enfield, NY, USA.

Singh D, Sharma R R. 2007 - Postharvest disease of fruit and vegetables and their management. In: Prasad, D edition sustainable pest management. Daya Publishing House, New Delhi, India.

Streets RT. 1969 - The diagnosis of plant diseases. The University of Arizona, Tucson, Arizona, USA.

Strobel GA, Mathre DE. 1970 - Outlines of Plant Pathology. D. Van Nostrand- Reinhold Co., NY, USA. 